\title{
Stenge, Csaba B. 2019. Forgotten Heroes: Aces of the Royal Hungarian Air Force in the Second World War. London: Helion \& Company. 438 pp.
}

\author{
Reviewed by Endre Szentkirályi, ${ }^{*}$ Nordonia Hills City Schools
}

In air force circles, an "ace" is a pilot who is credited with at least five enemy kills. Why should aficionados care about Hungary's Air Force during the Second World War, puny by comparison to other European countries? Quite simply, because the number of aces from Hungary are proportionally quite impressive. Dwarfed by countries like Germany, Finland, the U.S.A., and Norway, which had twenty-nine aces per million inhabitants (c. 1939), twenty-four aces, nine aces, and seven aces per million, respectively, Hungary nevertheless produced thirtyeight aces with a population of approximately nine million. When compared to countries two to five times its size, its proportional output of aces of about four per million inhabitants still beats Italy, Poland, and Romania (two-and-a-half to three aces per million inhabitants). In some sense, no less of an achievement is the work of Hungarian historian Csaba B. Stenge, who devoted the past two decades to researching the life stories of every single Hungarian ace. Forgotten Heroes: Aces of the Royal Hungarian Air Force in the Second World War is the product of his meticulous research, and this 438 page book is no less of a feat than flying a fighter aircraft during wartime: both require concentration, attention to detail, creativity, and persistence against all odds.

The book under review here is an updated translation of Stenge's 2016 edition of Elfelejtett hösök ['Forgotten Heroes']. Somewhat smaller in size and with black and white versus color pictures in the original Hungarian version published by Zrinyi Kiadó, this new and improved 2019 edition published by London-based Helion \& Company is a worthwhile addition to military history scholarship. With two Forwards, one by János Mátyás, an actual ace, written for the 2016 Hungarian edition, and a second one written by Dezső Szentgyörgyi Jr, the son of the top scoring Hungarian ace, the book's main feature is its biographies of all thirty-eight Hungarian aces, with extended summaries of their careers and detailed descriptions of their air combats. Forgotten Heroes is Stenge's second English-language monograph on Royal Hungarian Air Force history, the first being Baptism of Fire (2013, also by Helion \& Company). As such, Stenge's works are situated among Frank Olynyk's Stars \& Bars, a historical monograph on American aces, and Mihail Bikov's study of Soviet flying aces, Sovjetskie Asy 1941-1945 Pobedy Stalinskih. Not only is this new book an interesting read, but it also contains extremely useful supplementary material, such as air-combat tactics and methods, decorations,

\footnotetext{
*szentkiralyi@nordoniaschools.org
}

(cc) $\mathrm{EY}$

ULIS D-Serke
New articles in this journal are licensed under a Creative Commons Attribution 4.0 International License.

This journal is published by the University Library System of the University of Pittsburgh as part of its D-Scribe Digital Publishing Program and is cosponsored by the University of Pittsburgh Press 
comparative ranks, abbreviations, explanations and listings of units, and useful explanations of military concepts, including the vastly differing criteria that various countries used to award enemy kills. The only fault of the book is its lack of an index of names.

The compelling stories of air combat and subsequent life journeys of all of the aces, however, are the work of painstaking research, despite an appalling lack of official documentation in Hungarian government archives. This research is useful in and of itself, but it is doubly impressive because of the lengths to which Stenge had to go to acquire and verify the facts in these stories; almost all of the records of the Royal Hungarian Air Force during the Second World War were destroyed, and most of its officer corps was persecuted during communist times, so Stenge had to travel extensively to unearth these facts. Not only did he visit government and military archives in Russia, Germany, the United States, and Hungary, but he also found living relatives of many of the aces, tracking them down wherever they may have ended up after the war, including North and South America.

But let us look at some of the stories recounted by Stenge. Categorized into chapters by aces with more than twenty victories, those with more than ten, and those with five to nine confirmed kills, Stenge gives the reader details based not only on archival and family research, but he also interviewed the families of their victims and the families of their foes. When one reads about American and Soviet pilots who shot down these aces or who were shot down by them, one cannot help but admire the objectivity and empathy of Stenge's work. Filled with 350 rare photographs and images provided by the families on both sides of the war, the book gives a window to a previously unknown aspect of Hungary's military history. Some of the stories are heroic, such as one where Miklós Kenyeres rescued György Debrődy, a fellow pilot whose plane had just been shot down. Kenyeres landed next to the plane in knee-deep snow amid a hail of bullets; then, sitting the injured pilot into his own plane and himself in his lap, they flew home, with one controlling the pedals and the other the manual controls in a cockpit designed for a single pilot. Others are funny, like the picture of pilot Mátyás Lőrincz bathing in Lake Balaton, sitting in a boat modified from a droppable extra fuel tank of a P-51 Mustang airplane. And some are tragic, such as a bombing by Soviet aircraft during ace Lajos Buday's funeral in March of 1945, which killed a ground crew member in attendance as well as destroyed Buday's coffin. And all of the detailed descriptions of the thirty-eight Hungarian aces are enhanced by numerous contemporary maps and drawings unearthed by Stenge's research.

Another facet besides the fascinating stories that keeps this book from being a dry military history is that each biography contains at least a paragraph of the pilots' postwar lives. Some stayed in Hungary and continued as pilots in the new socialist air force until they were imprisoned by the communist authorities. Others emigrated to Western Europe, to Canada, to the United States, or to countries in South America, many becoming agricultural pilots and living out the rest of their lives in these new homelands. Interestingly enough, many of their sons and grandchildren eventually also became pilots. Striking also is that Stenge was able to interview many of these families, wherever in the world the pilots ended up. And in the most noteworthy example of turning swords into ploughshares, a Hungarian ace, after fleeing to the United States, became friends with many of his former adversaries, the former U.S. fighter pilots. But the most surprising fact of the book is that one Hungarian ace, László Dániel, ninety-seven years old, of Chile, was still alive at the time of its writing. These forgotten heroes, for forty-four years outcast as enemies of the state in Hungary, as imperialist reactionaries unfit to build the glorious socialist homeland, are no longer forgotten, due in no small part to Csaba B. Stenge's meticulous work. 